sociedade, relação entre técnica e política, condição de surgimento, tecnologia, ciência, tecnociência, conhecimento, híbrido, política, economia, atores sociais, Direito, segurança, nacionalismo, nacionalismo turvo, nacionalismo sustentável, político-conector, técnico-conector, Estado Relacional, Estado Instituidor do Social, Estado Legislador.

\title{
Valores e democracia em Cabo-Verde: entre adesão formal e embaraço cultural
}

Leão Domingos Jesus Lopes de Pina

Curso: Mestrado em Sociologia

Data da defesa: 26 de setembro de 2006

Nome do Orientador: Prof. Dr. Luís Augusto de Sarmento Gusmão

\section{Resumo}

Esta dissertação consiste numa descrição da cultura política cabo-verdiana atual e na sugestão de algumas de suas implicações para o sistema político democrático. A suposição de que essa cultura política tem no "perfil particularista" um de seus traços básicos se mostrou plausível, dado existir naquela sociedade uma indisposição (subjetiva) generalizada para se interagir cotidianamente com os concidadãos e com a maioria das instituições sociopolíticas. Evita-se a esfera pública e, muito provavelmente, privilegia-se, no estabelecimento de relações sociais e políticas, lógicas imanentes de ambientes privados (como a família), onde se encontra mais segurança, previsibilidade e reciprocidade. Disso advém a secundarização das regras universalistas, que é contrária aos pressupostos democráticos formais e institucionalmente estabelecidos. Tal imagem não condiz semanticamente com a percepção comum que se tem da categoria Morabeza - espécie de uma "supercordialidade 
crioula" - pretensamente expressão nítida do ethos cultural cabo-verdiano, espontaneamente democrática. Esta situação de "hibridismo institucional" é atualmente marcante na democracia cabo-verdiana que, por isso, está abarcada por uma relação tensa e embaraçosa entre o seu âmbito formal e o cenário cultural ao qual ele pretende se acoplar.

A nossa referência teórica básica é a chamada Escola Dominante de Cultura Política, fundada nos anos 60 por Almond e Verba e revisitada criticamente por um leque de autores a partir da década de 80. Para complementá-la, recorreu-se a outras noções, mais próximas à realidade dos países em desenvolvimento, como: "familismo amoral" (de Banfield e visitada por Reis), "hibridismo institucional" e "hobbesianismo social" (de Santos).

Palavras-chave: cultura política, democracia, cultura cívica, particularismo, hibridismo institucional, cabo-verdianidade, morabeza, cordialidade.

\section{Condições de vida no nordeste brasileiro: retratos da política local}

Fábio Alves

Curso: Mestrado em Sociologia

Data da Defesa: $1^{\circ}$ de dezembro de 2006

Orientadora: $\operatorname{Prof}^{\mathrm{a}} \mathrm{Dr}^{\mathrm{a}}$ Maria Francisca Pinheiro Coelho

\section{Resumo:}

O presente trabalho trata das relações entre condições de vida, cultura política e disponibilidade hídrica em municípios do Nordeste 